\title{
Heterosis Studies for Yield and Related Traits in CMS Based Onion (Allium cepa L.) Hybrids
}

\author{
Khade Yogesh Popat ${ }^{*}$, Sabina Islam ${ }^{2}$ and Subodh Joshi ${ }^{2}$ \\ ${ }^{1}$ ICAR-Directorate of Onion and Garlic Research, Rajgurunagar, Pune, Maharashtra, India \\ ${ }^{2}$ ICAR-Indian Agricultural Research Institute, Pusa Campus, New Delhi, India \\ *Corresponding author
}

\section{Keywords}

Short day CMS onion hybrids, heterosis, yield, bulb dimension and moisture content

Article Info

Accepted:

18 May 2020

Available Online:

10 June 2020

\section{A B S T R A C T}

The manifestation of heterosis for bulb yield and its component traits were studied in onion at ICAR-Indian Agricultural Research Institute, New Delhi. The main characters studied includes bulb yield, average bulb weight, bulb equatorial and polar diameter, neck thickness of plant and bulb, plant height, number of leaves and moisture content. It was studied in twelve CMS based short day onion hybrids and compared with commercial hybrid 'Flare'. All the hybrids were differed significantly for all the traits studied. The most promising hybrid PR-121×EG exhibited $81.60 \%$ heterobeltiosis and $79.70 \%$ standard heterosis. The other promising hybrids

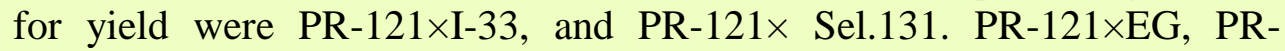
$121 \times$ Sel. 397 and PR-121 $\times$ PRO-6 were superior for polar and equatorial diameter of bulb, weight of ten bulbs, neck thickness of bulb and plant. Hybrids PR-121×Sel.102-1, PR-121×I 33, PR-121×Sel.383 were found best for moisture content.

\section{Introduction}

Onion (Allium cepa L.) is the second most important vegetable crop worldwide for mass consumption and is produced in almost all agro-climatic regions. Globally it covers 4.45 million hectare area with 85.94 million tonnes production having 19.30 tonnes per hectare productivity. In India it is grown in over 1.22 million hectare area producing 22.82 million metric tonnes at an average yield of 18.71 tonnes per hectare in 2014-15 (NHRDF,
2018). Onion accounts for 70 per cent of our total foreign exchange earnings from the export as fresh vegetables. Though India ranks second in production, its productivity is low as compared to other countries.

In order to achieve quantum jump in yield, it is always necessary to exploit Heterosis in all the crops. Since onion is a cross-pollinated crop, heterosis breeding provides an opportunity for improvement in its productivity, earliness, uniform size and yield 
attributing characters. Onion is one of the pioneer crop in which heterosis has been commercially exploited since about four decades. Although India is one of the leading producers of onion, not much emphasis was given to heterosis breeding in the past. In world, most of the area under onion cultivation is covered by open pollinated varieties and most of the hybrids are long day types. Hence, the emphasis should be given for the development of short day onion hybrids by using male sterile lines for higher yield and economization of cost of hybrid seed production (Evoor et al., 2007).

Till now, most of the hybrids available for commercial cultivation are produced by private seed companies only. But now-a-days public sector is also laying emphasis on development of hybrids by using male sterile lines (Evoor et al., 2007). Till today, very few reports are available regarding heterosis in CMS based short day onion hybrids suited to North Indian plains. So the present investigation was undertaken to know the extent of heterosis and identification of best combinations for yield and yield related traits in CMS based short day onion hybrids. So the present investigation was undertaken to know extent of heterosis and identification of best combinations for yield and yield components. The study related to heterosis in this crop was earlier done by Madalageri (1983), Gowda (1988), Aghora and Pathak (1991), Vinutha (2000) and Divakara (2001).

\section{Materials and Methods}

The experimental material comprised of twelve CMS based onion hybrids namely, PR121 $\times$ Sel.102-1, PR-121 $\times$ Sel.106, PR121 $\times$ Sel.121, PR-121 $\times$ Sel.126, PR121 $\times$ Sel.131, PR-121 $\times$ Sel.383, PR121×Sel.397, PR-121×Sel.402, PR-121×RO597, PR-121×I-33, PR-121×EG (Early Grano), PR-121 $\times$ PRO-6 and a commercial check hybrid Flare. These were evaluated in Randomized Block Design (RBD) with three replications at the experimental plots of the Division of Vegetable Science, ICAR-Indian Agricultural Research Institute, New Delhi. The parents were procured from different sources of India and maintained at Division of Vegetable Science as inbreds. The PR-121 line is male sterile line derived from Pusa Red. All the hybrids were developed in the experimental field under insect proof cages and hand pollination was carried out. The hybrids were sown in nursery in the third week of November and eight-weeks-old healthy seedlings of each hybrid were transplanted in the flat bed during third week of January. The plot size was $1.8 \mathrm{~m}^{2}$ and a planting distance of $15 \mathrm{~cm}$ between rows and $10 \mathrm{~cm}$ between plants was maintained. All the cultural operations like nursery raising, main field preparation, transplanting, fertilization, irrigation; weeding, plant protection etc. were carried out as per the recommendations in order to raise a successful crop.

Observations were recorded on 9 quantitative traits, viz., number of leaves per plant, plant height $(\mathrm{cm})$, neck thickness of plant $(\mathrm{mm})$, neck thickness of bulb (mm), vertical diameter of bulb $(\mathrm{mm})$, horizontal diameter of bulb $(\mathrm{mm})$, weight of bulb $(\mathrm{kg})$ and bulb shape index from ten randomly selected plants in each replication and mean was taken into consideration while estimation of heterosis. Bulb yield ( $\mathrm{t} / \mathrm{ha}$ ) was estimated from the average yield per plot in each replication. The magnitude of heterosis was computed as per cent increase or decrease in $\mathrm{F}_{1}$ over the means of better parent (BP) and standard check (SC) and the significance of results was examined with ' $t$ ' test.

\section{Results and Discussion}

The data regarding heterobeltiosis and standard heterosis for yield and related traits 
is presented in table 1 and 2 respectively. The heterobeltiosis for bulb yield in the present study was found to be in the range of -33.63 to 81.60 per cent with eleven crosses showing significant positive heterobeltiosis. The promising hybrid combinations are PR$121 \times \mathrm{EG} \quad(81.60 \%), \quad$ PR-121×Sel. 102-1 $(24.43 \%)$ and PR-121×Sel.39 (24.13\%). Out of twelve crosses, eleven crosses registered the significant positive standard heterosis for yield over commercial check hybrid Flare which is ranged from -34.32 to 79.70 per cent. The promising crosses are PR-121 $\times$ EG (79.70\%), PR-121 $\times$ I33 (33.28\%) and PR$121 \times$ Sel.131 (26.49\%). In the present study, yield was high i.e. $60.20 \mathrm{t} / \mathrm{ha}$ in PR-121×EG. This was a hybrid between short day type and long day introduction adapted to short day condition and that need to be given for multi locational testing. Among the short day $\times$ short day hybrids PR-121×I 33 (44.65 t/ha) was superior followed by PR-121×Sel. 102-1 (41.25 t/ha) and PR-121×Sel.397 (41.15 t/ha). Heterosis for yield in short day onion was earlier reported by Aghora and Pathak (1991), Fraga et al., (2001), Evoor et al., (2007) and Abubakar et al., (2008). Evoor et al., (2007) reported -30.14 to 45.31 per cent heterobeltiosis and -43.12 to 31.01 per cent standard heterosis, which is lower than the present study.

Bulb yield is a complex trait and average bulb weight, bulb diameter both equatorial and polar are the major component traits for bulb yield. The heterobeltiosis and standard heterosis for vertical diameter of bulb was observed in the range of -22.42 to 15.24 and 3.15 to $39.73 \%$, respectively. Promising crosses for heterobeltiosis were PR-121 $\times \mathrm{EG}$, PR-121 $\times$ Sel.397, PR-121 $\times$ Sel.121 and for standard heterosis PR- $121 \times \mathrm{EG}, \quad \mathrm{PR}$ $121 \times$ Sel.102-1, PR-121 $\times$ Sel.126 with nine and eleven crosses showing significant positive heterobeltiosis and standard heterosis respectively. In respect to horizontal diameter of bulb, the heterobeltiosis and standard heterosis ranged from -20.39 to 15.24 and 10.10 to 30.03 per cent respectively with only seven crosses showing significant positive heterosis. Promising crosses for heterobeltiosis were PR-121×EG, PR$121 \times$ Sel.121, PR-121 $\times$ PRO-6 and for standard heterosis were PR-121 $\times$ EG, PR$121 \times$ Sel. 121 , PR-121 $\times$ PRO-6 and only six crosses exhibited significant positive heterosis over commercial check hybrid Flare. For average weight of 10 bulbs heterobeltiosis was ranged from -53.84 to 36.36 per cent and standard heterosis ranged from -62.50 to 18.75 per cent. Five crosses exhibited significant heterobeltiosis, three hybrid combinations were at par with the better parent and four hybrids exhibited undesirable negative heterosis. The promising hybrids were PR-121×Sel. 397, PR-121×EG, PR$121 \times$ PRO-6. The hybrid between short day CMS and long day introduction adapted to short day (EG) exhibited significant positive standard heterosis and rest $11 \mathrm{CMS}$ hybrids had lower average bulb weight than the standard hybrid Flare.

The heterobeltiosis and standard heterosis for moisture content in bulbs ranged from -7.12 and 2.30 to 6.62 per cent, respectively. Only three crosses mainly PR-121 $\times$ Sel.102-1, PR$121 \times$ I 33, PR-121 $\times$ Sel.383 expressed the significant heterobeltiosis. Eight crosses shows significant standard heterosis with promising crosses like PR-121×Sel.102-1, PR-121×Sel. 383, PR-121×RO-597 over commercial check hybrid Flare. Evoor et al., (2007) reported better parent -26.80 to $15.67 \%$ heterobeltiosis and -24.87 to $1.1 \%$ standard heterosis for vertical diameter of bulb. For horizontal diameter of bulb, better parent heterosis ranged from -22.65 to $11.55 \%$ and standard heterosis -24.29 to $9.76 \%$. Our results are in line with the findings of by Madalageri (1983), Vinutha (2000) and Borgaonkar et al., (2005). 
Table.1 Heterobeltosis for yield and related traits in short day CMS hybrids

\begin{tabular}{|c|c|c|c|c|}
\hline $\begin{array}{l}\text { Sr. } \\
\text { No. }\end{array}$ & Characters & Range & $\begin{array}{c}\text { No. of desirable } \\
\text { heterotic hybrids }\end{array}$ & Best hybrid combinations \\
\hline 1 & Yield & -33.63 to 81.60 & 11 & PR-121×EG, PR-121×Sel.102-1, PR-121×Sel.397 \\
\hline 2 & Plant height & -10.75 to 8.53 & 4 & PR-121×EG, PR-121×Sel.402, PR-121×PRO-6 \\
\hline 4 & Horizontal diameter of bulb & -20.39 to 15.24 & 7 & PR-121×EG, PR-121×Sel.121, PR-121×PRO-6 \\
\hline 5 & Bulb shape index & -10.75 to 11.68 & 5 & PR-121×Sel.131, PR-121×Sel.402, PR-121×Sel.397 \\
\hline 8 & Neck thickness of bulb & -5.89 to 39.41 & 3 & PR-121×EG, PR-121×RO-597, PR-121×Sel.126 \\
\hline 9 & Weight of ten bulbs & -53.84 to 36.36 & 8 & PR-121×Sel.397, PR-121×EG, PR-121×PRO-6 \\
\hline 10 & Moisture content in bulbs & -7.12 to 2.30 & 3 & PR-121×Sel.102-1, PR-121×I-33, PR-121×Sel.383 \\
\hline
\end{tabular}

Table.2 Standard heterosis for yield and related traits in short day CMS hybrids

\begin{tabular}{|c|c|c|c|c|}
\hline $\begin{array}{l}\text { Sr. } \\
\text { No. }\end{array}$ & Characters & Range & $\begin{array}{l}\text { No. of desirable } \\
\text { heterotic hybrids }\end{array}$ & Best hybrid combinations \\
\hline 1 & Yield & -34.32 to 79.70 & 11 & PR-121×EG, PR-121×I-33, PR-121×Sel.131 \\
\hline 2 & Plant height & 12.38 to 49.33 & 12 & PR-121× Sel.121, PR-121×Sel.402, PR-121×Sel.397 \\
\hline 4 & Horizontal diameter of bulb & -10.10 to 30.03 & 6 & PR-121×EG, PR-121×Sel.121, PR-121×PRO-6 \\
\hline 5 & Bulb shape index & 4.28 to 27.14 & 12 & PR-121×Sel.126, PR-121×Sel.131, PR-121×Sel.102-1 \\
\hline 8 & Neck thickness of bulb & -34.96 to 33.94 & 9 & PR-121×Sel.131, PR-121×EG, PR-121×Sel.102-1 \\
\hline 9 & Weight of ten bulbs & -62.50 to 18.75 & 1 & PR-121×EG, PR-121×Sel.397, PR-121×PRO-6 \\
\hline 10 & Moisture content in bulbs & -2.67 to 6.62 & 8 & PR-121×Sel.102-1, PR-121×Sel.383, PR-121×RO-597 \\
\hline
\end{tabular}


For plant height, heterobeltiosis and positive heterosis varied from -10.75 to $8.53 \%$ and 12.38 to $49.33 \%$, respectively with four and all twelve crosses exhibiting significant heterobeltiosis and standard heterosis respectively. The maximum heterobeltiosis and standard heterosis for plant height was observed in the crosses like PR-121×EG, PR$121 \times$ Sel.402, PR-121 $\times$ PRO-6 and PR121 $\times$ Sel.121, PR-121 $\times$ Sel.402, PR$121 \times$ Sel.397, respectively. For number of leaves per plant, the heterobeltiosis and standard heterosis ranged from -39.55 to $18.79 \%$ and -23.84 to $49.67 \%$, respectively. Only three crosses PR-121×PRO-6, PR$121 \times$ Sel. 121, PR-121 $\times$ EG showed significant heterobeltiosis and ten crosses showed significant standard heterosis for this trait and promising crosses were PR-121 $\times$ PRO-6, PR$121 \times$ Sel. 121 , PR-121 $\times$ EG over commercial check hybrid Flare.

Evoor et al., (2007) reported better parent 17.98 to 13.07 per cent and standard parent 7.22 to 17.46 per cent. Similar results were reported by Netrapal et al., (1988), Madalageri (1983) and Divakar (2001). Our results are in conformity with the results obtained by earlier scientists. For number of leaves per plant similar results were obtained by Madalageri (1983), Gowda (1988), Sayed et al., (1999), Abubakar et al., (2008).

The lower neck thickness of plant and bulb is also desirable character. The heterobeltiosis for neck thickness of plant and bulb was observed in the range of $-20 . .62$ to $36.85 \%$ and -18.65 to $26.25 \%$ and standard heterosis ranged from -18.69 to $32.04 \%$ and -23.28 to $31.48 \%$, respectively. Four hybrids showed desirable negative heterobeltiosis for neck thickness of plant and bulb. Six hybrids showed desirable standard heterosis for neck thickness of bulb. The promising CMS hybrids for neck thickness were PR121×Sel.126, PR-121 $\times$ PRO-6 and PR-
121×Sel.131. Interestingly both Sel.126 and Sel.131 were rich in TSS. Evoor et al., (2007) reported -26.47 to $77.47 \%$ heterobeltiosis and -29.63 to $12.96 \%$ standard heterosis for neck thickness of bulb. These results were inconformity with Gowda (1988), Vinutha (2000) and Divakara (2001).

In the present study, not a single hybrid was found superior for all the traits studied. However, PR-121 $\times$ EG followed by PR$121 \times$ Sel.121 and PR-121 $\times$ PRO-6 were found best for bulb yield, vertical and horizontal diameter of bulb, weight of ten bulbs, neck thickness of bulb and plant. These hybrids need to be further studied for precise estimation of gene action for yield and related traits and they can also be given for multilocational testing for identification and recommending their commercial cultivation.

\section{References}

Abubakar L and Shehu GA. 2008. Heterosis of Purple blotch (Alternaria porri) resistance, yield and earliness in tropical onions (Allium cepa L.). Euphytica, 164: 63-74.

Aghora TS and Pathak CS. 1991. Heterosis and combining ability in line $\mathrm{x}$ tester cross of onions. Vegetable Science, 18: 53-58.

Borgaonkar SB, Vaddori A, Dhaduk HL and Poshiya VK. 2005. Heterosis in onion. Agricultural science digest, 25(4): 251253.

Divakara MS. 2001. Heterosis and combining ability studies for bulb yield, its components and quality parameters in onion. M.Sc. (Agri.) thesis, University of Agriculture Sciences, Dharwad, India.

Evoor S, Gowda RV, Gangappa E and Monohar RK. 2007. Heterosis for yield, yield components and quality traits in onion (Allium cepa L.). Karnataka 
journal of agricultural science, 20(4): 813-815.

Fraga A, Perez NA, Fundora Z, GonzalezChavez M, Prats A, Rodriguez A and Del MC. 2001. Heterosis of yield and its components in an onion crop. Alimentaria, 38(328): 79-82.

Gowda V. 1988. Studies on the genetics of yield and quality characters in bulb and seed crop of onion (Allium cepa L.). $\mathrm{Ph} . D$. thesis, University of Agriculture Sciences, Bangalore, India.

Madalageri BB. 1983. Studies on heterosis, combining ability and gene actions for quantitative characters in bulb onions. $\mathrm{Ph} . D$. thesis, University of Agriculture
Sciences, Bangalore, India.

Netrapal. 1988. Heterosis for yield and storage parameters in onion. Indian journal of agricultural sciences, 69(12): 826-829.

NHRDF (2018). www.nhrdf.org/enus/AreaandProductiion.

Sayed AM, Atia AM, Hak SHG, Agab AM and Mohamed MY. 1999. Studies on heterosis, gene action and combining ability of some traits in onion. Egyptian Journal of Horticulture, 26: 85-95.

Vinutha B. 2000. Heterosis in relation to parental diversity in onion (Allium cepa L.). M.Sc. (Agri.) thesis, University of Agriculture Sciences, Dharwad, India.

\section{How to cite this article:}

Khade Yogesh Popat, Sabina Islam and Subodh Joshi. 2020. Heterosis Studies for Yield and Related Traits in CMS Based Onion (Allium cepa L.) Hybrids. Int.J.Curr.Microbiol.App.Sci. 9(06): 2477-2482. doi: https://doi.org/10.20546/ijcmas.2020.906.300 